\title{
Short-lived tectonic switch mechanism for long-term pulses of volcanic activity after mega-thrust earthquakes
}

\author{
M. Lupi ${ }^{1}$ and S. A. Miller ${ }^{2}$ \\ ${ }^{1}$ ETH Zurich, Department of Earth Sciences, Zurich, Switzerland \\ ${ }^{2}$ Steinmann Institue, Geodynamics/Geophysics, University of Bonn, Bonn, Germany \\ Correspondence to: M. Lupi (matteo.lupi@erdw.ethz.ch)
}

Received: 23 May 2013 - Published in Solid Earth Discuss.: 27 June 2013

Revised: 5 November 2013 - Accepted: 6 November 2013 - Published: 6 January 2014

\begin{abstract}
Eruptive rates in volcanic arcs increase significantly after subduction mega-thrust earthquakes. Over short to intermediate time periods the link between mega-thrust earthquakes and arc response can be attributed to dynamic triggering processes or static stress changes, but a fundamental mechanism that controls long-term pulses of volcanic activity after mega-thrust earthquakes has not been proposed yet.

Using geomechanical, geological, and geophysical arguments, we propose that increased eruption rates over longer timescales are due to the relaxation of the compressional regime that accompanies mega-thrust subduction zone earthquakes. More specifically, the reduction of the horizontal stress $\sigma_{h}$ promotes the occurrence of short-lived strike-slip kinematics rather than reverse faulting in the volcanic arc. The relaxation of the pre-earthquake compressional regime facilitates magma mobilisation by providing a short-circuit pathway to shallow depths by significantly increasing the hydraulic properties of the system. The timescale for the onset of strike-slip faulting depends on the degree of shear stress accumulated in the arc during inter-seismic periods, which in turn is connected to the degree of strain-partitioning at convergent margins.

We performed Coulomb stress transfer analysis to determine the order of magnitude of the stress perturbations in present-day volcanic arcs in response to five recent megathrust earthquakes; the 2005 M8.6, 2007 M8.5, and 2007 M7.9 Sumatra earthquakes; the 2010 M8.8 Maule, Chile earthquake; and the 2011 M9.0 Tohoku, Japan earthquake. We find that all but one the shallow earthquakes that occurred in the arcs of Sumatra, Chile and Japan show a marked lateral component. We suggests that the long-term response of vol-
\end{abstract}

canic arcs to subduction zone mega-thrust earthquakes will be manifested as predominantly strike-slip seismic events, and that these future earthquakes may be followed closely by indications of rising magma to shallower depths, e.g. surface inflation and seismic swarms.

\section{Introduction}

One of the fundamental uncertainties in earth science is the mechanism controlling volcanism in compressional environments. Horizontally oriented stresses during compression produce high confining pressures on incipient flow paths, suppressing vertical flow. Instead, this favours sill development when the pressure of magma at depth exceeds the minimum principal stress. Reviews of the structural and petrological characteristics of volcanic systems associated with reverse and strike-slip faults (Tibaldi et al., 2010) show how evolutionary effects of the local stress field affect eruption rates and volcanic behaviours. Over non-geological time periods, the complexity of these systems is partially due to variations in the loading environment throughout mega-thrust earthquake cycles, from sub-horizontal compression during convergence, to short-lived viscoelastic relaxation during post-seismic periods. Indeed, volcanic belts in convergent margins undergo different tectonic regimes that either restrict or promote vertical migration of deep fluids and magmas by the cyclic loading and unloading of the effective normal stress caused by the recurrence of mega-thrust slips at the subduction interface. 
A link between mega-thrust earthquakes and volcanic activity was first recognised by Charles Darwin when he noted increased volcanism in Chile following the M8.5 Conceptión 1835 earthquake (Darwin, 1840). Seismically induced volcanic activity with varying time- and space-scales is now recognised around the globe (Eggert and Walter, 2009), with examples from the USA (Lipman and Mullineaux, 1981; Sanchez and McNutt, 2004), Kamchatka (Walter, 2007), Central America (Williams and Self, 1983; White and Harlow, 1993), Japan (Koyama, 2002), and Italy (Sharp et al., 1981; Nercessian et al., 1991; Marzocchi et al., 1993; Nostro et al., 1998).

Triggered volcanic activity spans a range of timescales and distances (Hill et al., 2002; Delle Donne et al., 2010). In the immediate or short term associated with passing seismic waves, mechanical perturbation of the magma reservoir may result in processes such as rectified diffusion, gas exsolution, and/or unclogging of migration pathways (Hill et al., 2002; Brodsky and Prejean, 2005; Manga and Brodsky, 2006). Such processes may also be enhanced by the overall geological structure at depth (Lupi et al., 2013). Examples include the Kamchatka M9.0 earthquake in 1952 (Johnson and Satake, 1999), which was followed by eruptions of the Karpinsky and Tao-Rusyr volcanoes one and seven days, respectively, after the main shock (Walter and Amelung, 2007), and the Minchinmavida and Cerro Yanteles volcanoes that erupted less than 24 hours after the Conceptión, Chile, earthquake (Darwin, 1840; Cembrano and Lara, 2009).

Static stress changes induced by slip on the subduction interface develop at short to intermediate timescales, principally by relaxing the normal stress that acts on incipient flow pathways (Cembrano and Lara, 2009). The delay between earthquakes and volcanic unrest can extend to years, with some relationship of the hypo-central distance to the volcanic system (Walter and Amelung, 2007). The rising speed of the magma is principally driven by the content of volatiles in the melt (e.g. Sigurdsson et al., 1999). Hence, it is not possible to address any relationship between the depth of the magmatic reservoir and the delay of the eruption. However, few examples may provide some insights about the timescale of these processes. For instance, a M8.3 subduction earthquake in 1923 in Kamchatka triggered many subsequent volcanic eruptions in the region, with two in 1923, one in 1925, two in 1926, and one each in 1927, 1928, 1929 and 1930 (Eggert and Walter, 2009). More recent examples include the Planchón-Peteroa, Puyehue-Cordón Caulle, and Copahue volcanoes that erupted approximately seven, sixteen, and thirty-four months after the M8.8 February 2010 Maule earthquake, respectively. The mechanism driving static stress triggering at intermediate to long timescales remains unclear, but recent studies (Walter and Amelung, 2007; Bonali et al., 2012) suggest that reductions of the effective stress in response to slip along mega-thrust subduction interfaces may contribute to magma mobilisation.
In this paper we expand on this concept to explore longterm and evolving changes in the stress state in the arc following mega-thrust subduction zone earthquakes. We propose a mechanism that operates at timescales greater than the immediate effects of dynamic-stress triggering and long after static stress changes from mega-thrust earthquakes have perturbed the system. We explore the mechanical consequences of a decadal change in the kinematics associated with the post-seismic relaxation and suggest that the tectonic switch from pre-earthquake compression to post-earthquake relaxation results in a dominantly strike-slip stress state emplaced during the "less compressive" time window that follows mega-thrust slips. In this context, increases of crustal permeability via normal stress reduction and strike-slip faulting become the most efficient mechanism for vertical migration of melts and deep slab-derived trapped fluids.

\section{Short-lived tectonic switch: proposed mechanism}

We hypothesise that long-term increase in arc volcanism is kinematically controlled whereby post-seismic relaxation of the compressional stress regime initiates short-lived strikeslip kinematics in the volcanic arc. The onset of strike-slip faulting is controlled by (i) the degree of strain partitioning at convergent margins, (ii) the inter-seismic duration that controls the shear stress amplitudes, and (iii) the relative values of the vertical $\sigma_{v}$ and horizontal $\sigma_{h}$ principal stresses before the mega-thrust earthquake. The onset of strike-slip faulting promotes an increase of volcanic activity because it provides a short-circuit pathway for upwelling fluids and magmas. Strike-slip faulting dramatically increases the vertical permeability of the crustal transport network and may induce high strain rates in the magmatic reservoir if the magmatic chamber is affected by the fault plane (Chaussard et al., 2013).

The degree of strain-partitioning strongly affects the switch from reverse to strike-slip environments (Chemenda et al., 2000). In addition, the closer the absolute values of $\sigma_{h}$ and $\sigma_{v}$ are before the mega-thrust earthquake, the more the switch from reverse to strike-slip faulting is favoured. The mechanical argument is illustrated in the 3-D Mohr diagram in Fig. 1. In compressive subduction systems, thrust faulting is favoured prior to mega-thrust earthquakes, with the maximum principal stress $\left(\sigma_{1}=\sigma_{H}\right)$ assumed to be horizontal in the direction of convergence, the minimum principal stress $\left(\sigma_{3}=\sigma_{v}\right)$ vertical (weight of the overburden), and the intermediate principal stress $\left(\sigma_{2}=\sigma_{h}\right)$ also horizontal and orthogonal to $\sigma_{H}$. This stress state favours sill development and thrust faulting but hinders vertical dike formation and propagation (Tibaldi et al., 2010). The maximum shear stress developed during compression is $\tau_{\max }=\left(\sigma_{H}-\sigma_{v}\right) / 2$ and it is proportional to the angle of incidence of the ongoing subduction (Chemenda et al., 2000). In this stress state, optimally oriented faults are thrust faults dipping at around $30^{\circ}$ 

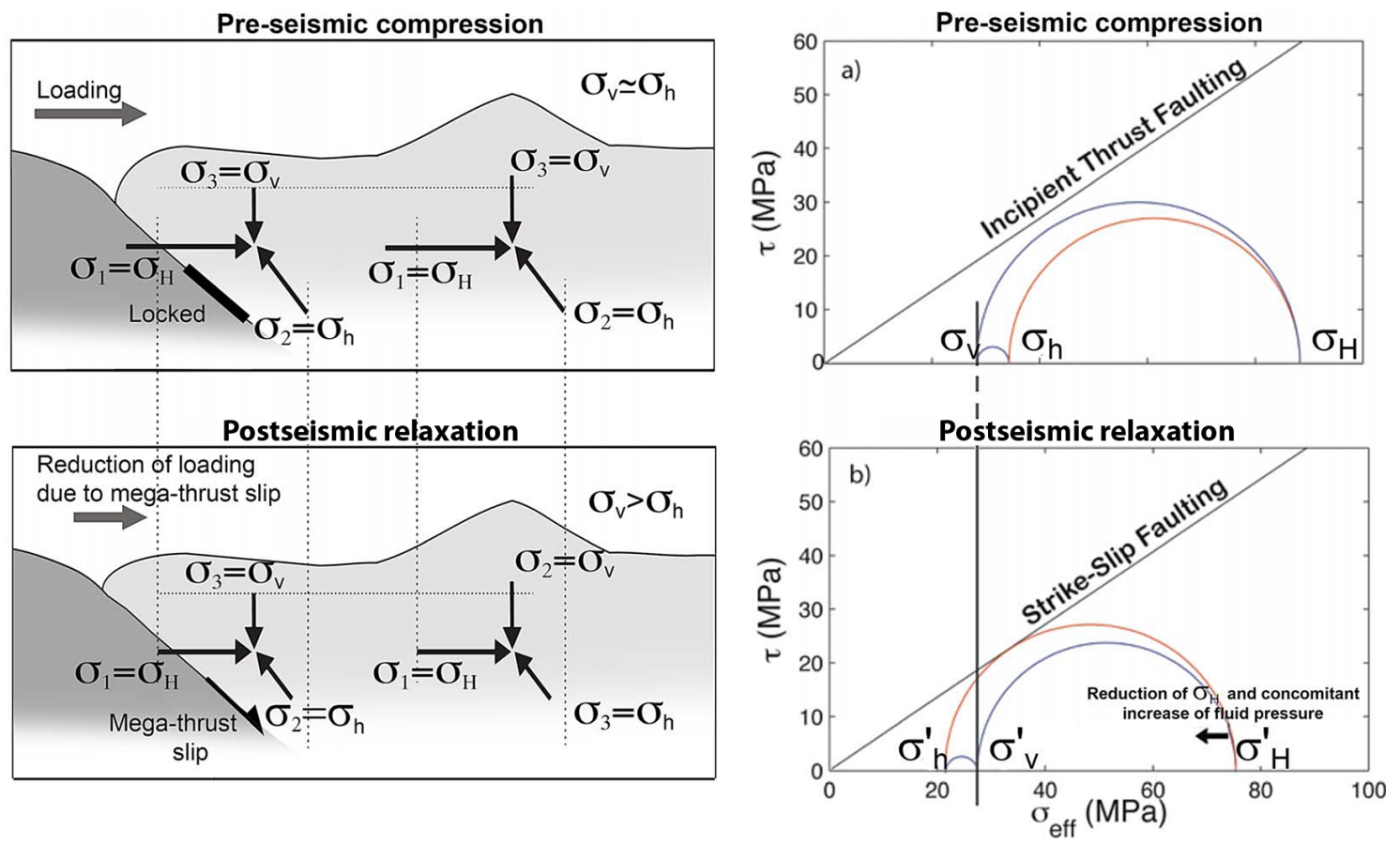

Fig. 1. Mechanical argument for a long-term increase in volcanism following mega-thrust earthquakes. The stress state during compression (loading) encourages thrust faulting and sill development, but limits vertical fluid flow. Beneath the arc, the value of $\sigma_{v}$ is higher (and close to $\sigma_{h}$ ) than at same depths in the fore-arc region. Post-seismic unloading reduces the maximum horizontal stress, while simultaneously increasing vertical permeability (increasing fluid pressure) due to the reduction in fault normal stress. Due to the reduction of $\sigma_{H}$ and moreover $\sigma_{h}, \sigma_{v}$ becomes the intermediate principal stress initiating strike-slip faulting in the arc.

assuming a friction coefficient of 0.6. Slip along the megathrust interface predominantly relaxes $\sigma_{H}$. Ignoring poroelastic effects, $\sigma_{H}$ and $\sigma_{h}$ are coupled. Both $\sigma_{H}$ and $\sigma_{h}$ are continuously reduced during the relaxation process even though $\sigma_{h}$ is reduced at a lower rate. The overburden $\sigma_{v}$ remains unchanged, so if $\sigma_{h}$ reduces below $\sigma_{v}$ the stress state in the arc emerges as a strike-slip regime. The time required to achieve strike-slip faulting depends on the stress difference between $\sigma_{h}$ and $\sigma_{v}$ prior to the mega-thrust earthquake. For this reason, the switch from reverse to strike-slip regimes is favoured in the arc where $\sigma_{v}$ and $\sigma_{h}$ are closer (Fig. 1). This implies that, compared to fore- or back-arc regions, smaller reductions of $\sigma_{h}$ are needed beneath the volcanic arc for $\sigma_{v}$ to become the intermediate principal stress.

\subsection{Supporting arguments}

Geochemical studies in arc lavas suggest transport of slabderived fluids originated at depth and mobilised over short timescales (e.g. Sigmarsson et al., 1990, 2002). A textbook example that illustrates the mechanism proposed in this paper is provided by the recent evolution of the Laguna del Maule system, which is a volcanic complex located in the fold and thrust belt of Central Chile, facing the main slip of the Maule earthquake. InSAR studies highlight an inflation phase that began in 2007 and reached an average value of $227 \mathrm{~mm} \mathrm{yr}^{-1}$ in early 2012 (Feigl, 2013). The inflation strongly and suddenly accelerated to $388 \mathrm{~mm} \mathrm{yr}^{-1}$ after the occurrence of a strike-slip M6.0 earthquake on 17 June 2012, which occurred beneath the volcanic system (Fig. 2). An example of a magmatic province that was likely developed during a period of extension or strike-slip faulting are the Sierra Nevada Batholiths, California, which are thought to have formed as soon as compression ceased (Tikoff and Greene, 1997). In addition, Mazzini et al. (2009) show that strike-slip faulting may favour the development of piercement structures and faulting as a mechanism for seismic pumping of deeply trapped fluids has been proposed by Sibson et al. (1975), and contributed to explain aftershock sequences in the Italian Apennines (Miller et al., 2004), or the emplacement of ore deposits (Cox and Ruming, 2004).

Our conceptual model is also consistent with other speculative but yet intriguing examples where magma mobilisation is restricted during thrusting and accelerates significantly once large part of the compressive stress is removed via large-scale slip on the subduction zone interface. For instance, studies of crystal growth (Druitt et al., 2012) show that Santorini volcano, Greece, lay dormant for $18 \mathrm{kyr}$ before evolving into a caldera-forming eruption (ca. $1600 \mathrm{BC}$ ) in a mere 100 yr. Driessen and Macdonald (1997) highlight the occurrence of seismically induced ruins of the Minoan civilisation on the isle of Thera pre-dating the eruption of 

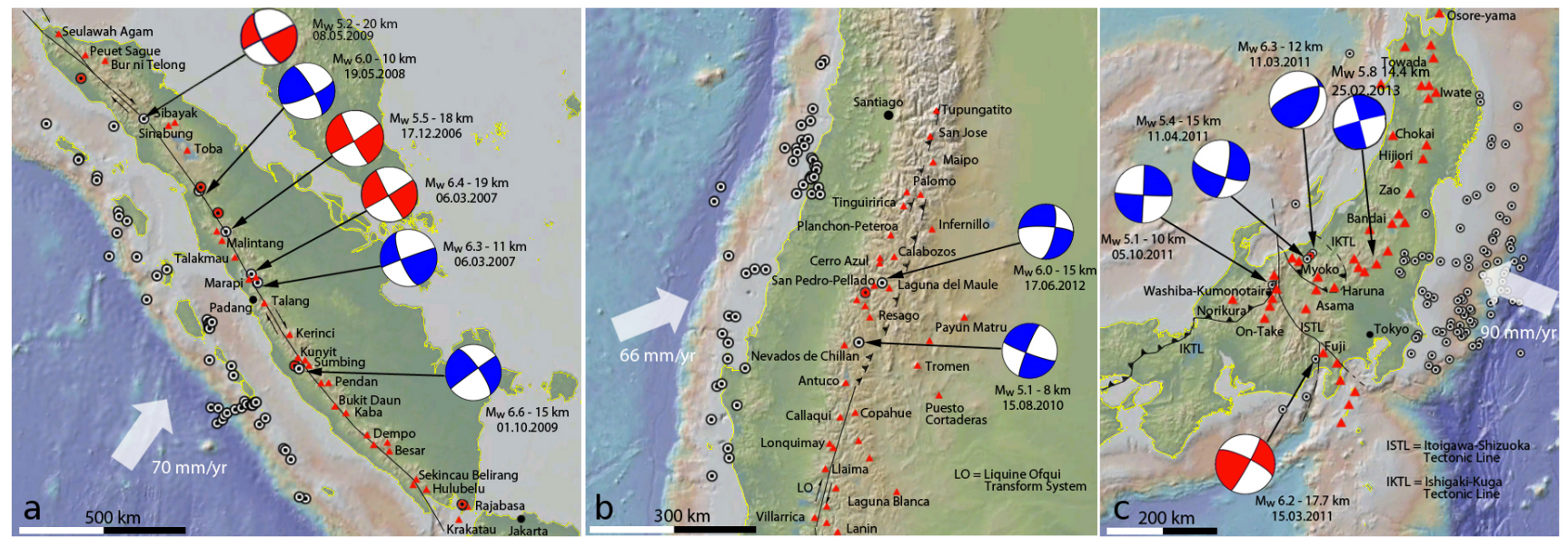

Fig. 2. Maps of Sumatra, Chile, and Japan showing locations of shallow aftershock events that followed the mega-thrust events of Sumatra (M8.7, M8.4, M7.9), Maule (M8.8), and Tohoku (M9.0). Blue focal mechanisms identify seismic events with focus depths shallower than $15 \mathrm{~km}$ whereas red focal mechanisms show events deeper than $15 \mathrm{~km}$ but shallower than $20 \mathrm{~km}$. The depth range was selected to identify crustal events only (i.e. relevant to brittle deformation of the arc). Focal mechanisms of seismic events with magnitudes smaller than M5 were not always available from USGS, ESMC, and GMT online catalogues and were therefore not plotted to avoid biased estimates of ongoing crustal deformation. White and black-cored circles indicate aftershock activity M $>$ M5 at the subduction interface while red and black-cored circles indicate seismic events $(\mathrm{M}>\mathrm{M} 5)$ in the arc for which focal mechanisms are not available. All the focal mechanism plotted here can be retrieved from the CMT seismic catalogue.

Santorini. Given that the earthquake occurred on the Hellenic subduction zone, this event is consistent with our hypothesis where a mega-thrust earthquake transformed the stress state in the arc hosting Santorini into extension or transtension, and possibly initiated the observed rapid magma mobilisation. Another example is the most recent eruption of the Chaitén volcano, Chile, that entered a new eruptive phase in May 2008 after more than $9 \mathrm{kyr}$ of dormancy. Wicks et al., 2011 suggest that mobilisation of the viscous rhyolitic magma that fed the eruption was accelerated by the introduction of (mechanically created) permeability and pressurisation of the magmatic chamber due to the 1960 Valdivia mega-thrust earthquake. Interestingly, a temporary network deployed in 2004 and 2005 around the Chaitén volcano showed clusters of seismicity at the source of that eruption with strike-slip focal mechanisms (Wicks et al., 2011). Finally, Mount Sinabung in Sumatra, after $400 \mathrm{yr}$ of quiescence, erupted in August and September 2010, $5 \mathrm{yr}$ after the 2005 M8.6 Nias earthquake. The Sinabung volcano, which resides upon the Great Sumatran strike-slip fault, is located about $180 \mathrm{~km}$ east of the region of maximum slip during the Nias earthquake (Hendrasto, 2011).

\section{Strain partitioning and observed focal mechanisms in the arc}

If strike-slip faulting contributes to magma mobilisation, then it is important to determine to what extent strike-slip faults in the arc were perturbed from slip on the subduction interface. Figure 3 shows the tectonic settings, the slip distributions, and the direction of the volcanic arcs for Sumatra, Chile, and Japan. In oblique subduction zones the shear component is accommodated in the overriding plate by trenchparallel, regional-scale, strike-slip faults that are localised within the volcanic belt because of the higher geothermal gradients. Several authors investigated the dynamics of strain partitioning using mathematical (Platt, 1993; Braun and Beaumont, 1995), experimental (Pinet and Cobbold, 1992; Burbidge and Braun, 1998), and field (Rosenau et al., 2006) studies. Fitch (1972) suggests that the strike-slip component relates linearly to the incidence angle of the subduction, with some relation between normal and shear stresses. Chemenda et al. (2000) highlight that the degree of stress partitioning is proportional to the rate of along-trench translation and inversely proportional to the convergence rate and incidence angle. These observations are consistent with the behaviour in the oblique-subducting margins of Chile and Sumatra where strain is partitioned and where strike-slip faulting occurs in the arc (Fig. 2). Little partitioning is expected in Japan because of the frontal collision. However, some strikeslip faulting following the Tohoku earthquake was observed along the periphery of the perturbed regions, and close to the Itoigawa-Shizuoka and Ishigaki-Kuga tectonic lines, in proximity of mapped reverse faults. This is in agreement with a progressive reduction of $\sigma_{h}$, which promotes $\sigma_{v}$ to become the intermediate principal stress. However, fault reactivation and magma mobilisation are not always coupled and when this happens (i.e. Laguna del Maule) many (unknown) factors (such as crustal permeability, magma viscosity, current 
stress-state of the volcanic system) may affect the time delay between faulting and magma mobilisation.

\section{Coulomb stress transfer to the arc}

Coulomb stress transfer is a commonly used tool to determine the change in normal and shear stress on defined planes (receiver faults) due to slip on elastic dislocations in a threedimensional half-space (King et al., 1994; Stein, 1999; Toda et al., 2011). We performed Coulomb stress analysis using published slip distributions (USGS, 2010; Ji, 2013) as the source faults for the 2005 M8.6, 2007 M8.5, and 2007 M7.9 Sumatra earthquakes; the 2010 M8.8 Maule, Chile earthquake; and the 2011 M9.0 Tohoku, Japan earthquake. As receiver faults we used the strike, dip, and rake angle provided by moment tensor solutions of shallow (less than $20 \mathrm{~km}$ deep) strike-slip earthquakes listed in the CMT catalogs that occurred in each of the volcanic arcs following the mega-thrust earthquake. Moment tensor solutions for seismic events weaker than M5 are not always available. We only account for the focal mechanism of events larger than M5. We also acknowledge the sensitivity of Coulomb analyses to the selected parameters. Here we are only concerned about the order of magnitude of the stress variations imparted in the arc by the mega-thrust earthquake.

\subsection{Sumatra}

Oblique convergence in Sumatra is accommodated by trench-normal subduction and trench-parallel transform motion along the Sumatra transform fault. Three mega-thrust subduction zone earthquakes occurred in 2005 and 2007, producing trench-normal slip along most of the island. We do not consider the 2004 M9.2 earthquake because slip from that earthquake occurred primarily to the north of Sumatra where there is no arc. Substantial shear stress along the Sumatran fault is expressed by the occurrence of six $M>5.0$ strike-slip faulting events between 2006 and 2009. Figure 4 shows that the regions where these events occurred were mechanically perturbed by the mega-thrust slip either by increase of shear or normal stress. In the first case, seismic or aseismic lateral slip may shear the magmatic reservoir (for instance located upon the Great Sumatran Fault) reducing its effective viscosity by orders of magnitude and thus enhancing its mobility. In the second case, the reduction of normal stress promotes an increase of permeability and the upwelling of deep fluids that further reduce the effective normal stress bringing faults closer to failure. Based on this we would expect additional events with strike-slip focal mechanism to occur within the next years as post-seismic relaxation of the compressional regime will continue to trigger the transform component of strain-partitioning.

\subsection{Chile}

The region that faces the slip of the M8.8, 2010, Maule earthquake is located north of the Liquiñe-Ofqui transform system, but oblique convergence of the Nazca and South American plates also provides for shear stress development in the thick and old crust north of $37^{\circ} \mathrm{S}$. This is shown by two $\mathrm{M}>5$ strike-slip earthquakes that occurred 6 months and 30 months after the Maule earthquake in the fold and thrust belt of Central Chile (Bonali et al., 2012), where lateral motion is not highlighted by mapped strike-slip faults. In the Coulomb analysis in Fig. 5, we choose receiver faults with strike, dip, and rake determined from moment tensor solutions of the M6.0 strike-slip event in the Chilean arc.

The results in Fig. 5 refer to the fault plane subparallel to the direction of the arc; results for the antithetic fault plane striking NW-SE are discussed later. The stress transfer analysis shows effects of the Maule earthquake, and highlights that fault planes subparallel to the direction of the arc were loaded towards failure. Although much of the Coulomb failure stress is due to the reduction of the normal stresses, we also observe a remarkable increase in shear stress. Figure 5 (post-seismic state) shows increased shear and reduced normal stress where observed strike-slip focal mechanisms occurred, indicating that the stress state in the arc is currently accommodating the lateral component.

\subsection{Japan}

In Japan, strain partitioning is negligible because of the nearly frontal subduction of the Pacific Plate beneath the Eurasian Plate. This is also confirmed by the reverse focal mechanisms of large magnitude seismic events occurring in the Japanese arc before the 11 March 2011 mega-thrust earthquake (i.e. on 13 June 2008 or 20 September 2010). The distribution of the volcanic systems in the Japanese arc may also reflect the absence of a through-going strike-slip fault system (Nakamura et al., 1977). The strike-slip focal mechanisms that immediately followed the Tohoku earthquake are located in complicated regions that accommodate the differential (strike-slip) motion of the Pacific and Philippine plates with respect to the Eurasian Plate. Strike-slip seismic events (blue circles of Fig. 2c) occur in regions characterised by thrust faulting (i.e. close to the Kuroiwayama, Furumi, Juchihara, and Zenkoji faults - see AIS for a complete database of Japanese faults). The reactivation of such systems with strike-slip kinematics can be explained by the short-lived tectonic switch illustrated in Fig. 1. Figure 6 shows a Coulomb stress transfer analysis from the slip of the M9.0 2011 Tohoku earthquake (USGS, 2010). As receiver fault we used the plane subparallel to the direction of the arc identified by the focal solution of a M5.4 event (11 April 2011). The analysis shows that the entire region was mechanically perturbed and faults were brought closer to failure, consistently with static stress transfer as an earthquake triggering mechanism. 

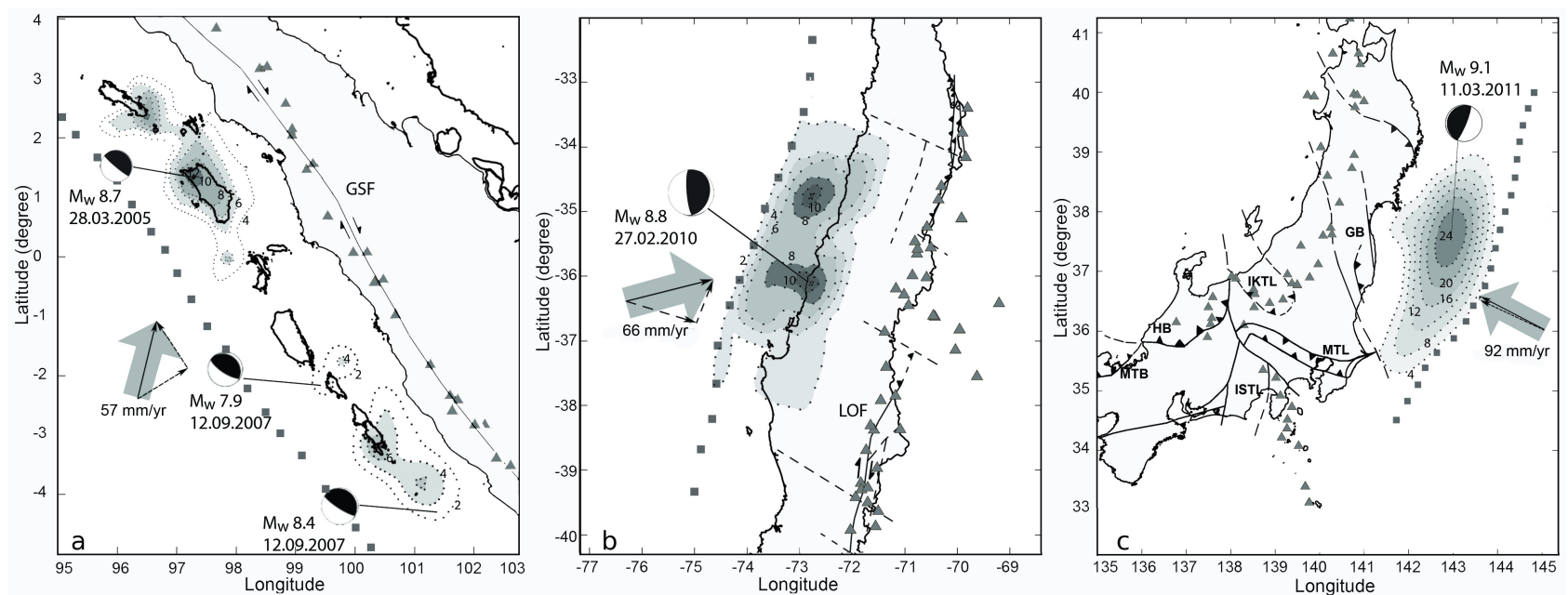

Fig. 3. Tectonic setting and co-seismic slip of the Sumatran, Chilean, and Japanese earthquakes. (a) The M8.7 Nias earthquake occurred on 28 March 2005 at the interface between the Sunda and Australian plates. The maximum slip was calculated to be approximately $14 \mathrm{~m}(30 \mathrm{~km}$ deep) with a rupture plane striking $\mathrm{N}^{\circ} 35$ and dipping $15^{\circ}$, which propagated laterally for approximately $400 \mathrm{~km} \mathrm{NW-SE}$ and for more than $180 \mathrm{~km}$ down-dip (USGS, 2010). The M8.4 and M7.9 Sumatran earthquakes occurred on September 122007 and caused maximum slips of 4 and $7 \mathrm{~m}$, respectively. (b) The M8.8 Maule earthquake struck Chile on 27 February 2010 rupturing the Concepción-Constitucion gap at the interface of the Nazca and South America plates. The slip plane $\left(18^{\circ} \mathrm{NE}, 18^{\circ} \mathrm{S}\right.$ dip $)$ ruptured for more than $100 \mathrm{~km}$ downdip and extended approximately $500 \mathrm{~km}$ in the north-south direction (USGS, 2010)) inducing a maximum slip of $14 \mathrm{~m}$ at $35 \mathrm{~km}$ depth (?). (c) The M9.0 Tohoku earthquake struck Japan on 11 March 2011, close to the northeast coast of Honshu, Japan, where the Pacific Plate subdues beneath the North America Plate. The slip plane (striking N $340^{\circ}$ and dipping is $14^{\circ} \mathrm{WNW}$ ) propagated $400 \mathrm{~km}$ along strike and $150 \mathrm{~km}$ in the dip direction with a maximum slip of $24 \mathrm{~m}$ according to USGS. GSF and LOF stand for Great Sumatran Fault and Liquiñe-Ofqui Fault system, respectively. ISTL stands for Itoigawa-Shizuoka Tectonic Line, MTL for Median Tectonic Line, IKTL for Ishigaki-Kuga Tectonic Line, MTB for Mino-Tanba Belt, GB for Gosaisho Belt, HB for Hida Belt

\section{Discussion}

Sumatra, Central Chile and Japan constitute a spectrum of strain partitioning, and therefore the behaviour of their respective arcs may record this. The Coulomb stress transfer analysis in Sumatra, Chile, and Japan shows that earthquakes with strike-slip focal mechanisms were all brought closer to failure after each of the mega-thrust earthquakes. We recognise that stress transfer results are sensitive to many of the input parameters, and the results can change with uncertainties in the slip distribution and/or the orientation or slip of the receiver faults. Nevertheless, the general behaviour of volcanic arcs is consistent with the Coulomb stress transfer picture that emerges. Namely, a strike-slip regime is activated by mega-thrust earthquakes with an apparent correlation between the degree of strain partitioning and the number of strike-slip earthquakes. Although the time window is different between the three systems (with Japan being the most recent event), there have been six large strike-slip events in the Sumatran arc, two in Chile (far from the Liquiñe-Ofqui transform system), and one in the arc directly behind the Tohoku rupture zone (four around the tectonically complex Itoigawa-Shizuoka and Ishigaki-Kuga tectonic lines).

Geological and geophysical observations show that strain partitioning is most pronounced in Sumatra where the high obliquity of convergence between the Australian and Sunda plates results in convergence accommodated by subduction and the strike-slip component taken up by the Great Sumatran Fault. The recent large intra-oceanic plate earthquakes off Sumatra (Duputel et al., 2012) now appear to also take up some strike-slip component, but the existence of the throughgoing Great Sumatran Fault indicates significant shear stress development along the arc. In Central Chile, where a welldeveloped lateral transport system is not apparent, focal mechanisms of recent events confirm that considerable shear stress has developed in the arc (see also Cembrano and Lara (2009) for additional focal mechanisms).

Focal mechanisms are ambiguous as to which fault plane failed. In Sumatra, the likely true fault plane is subparallel to the strike of the Sumatra Fault, while in Japan there appears to be no visible strike-slip system in the arc behind the Tohoku slip zone. Central Chile, where the Maule earthquake occurred, is interesting because it lies to the north of the through-going Liquiñe-Ofqui Fault, and does not appear to exhibit a regional scale strike slip system. Tectonic settings controlled by a strong compressional component show a general diffuse distribution of volcanic centres (Nakamura et al., 1977), with a direct correlation between convergence and diffusion of the volcanic systems (Tibaldi et al., 2010). This is consistent with the diffuse distribution of volcanoes in Japan. In Sumatra, volcanic centres are aligned along the 

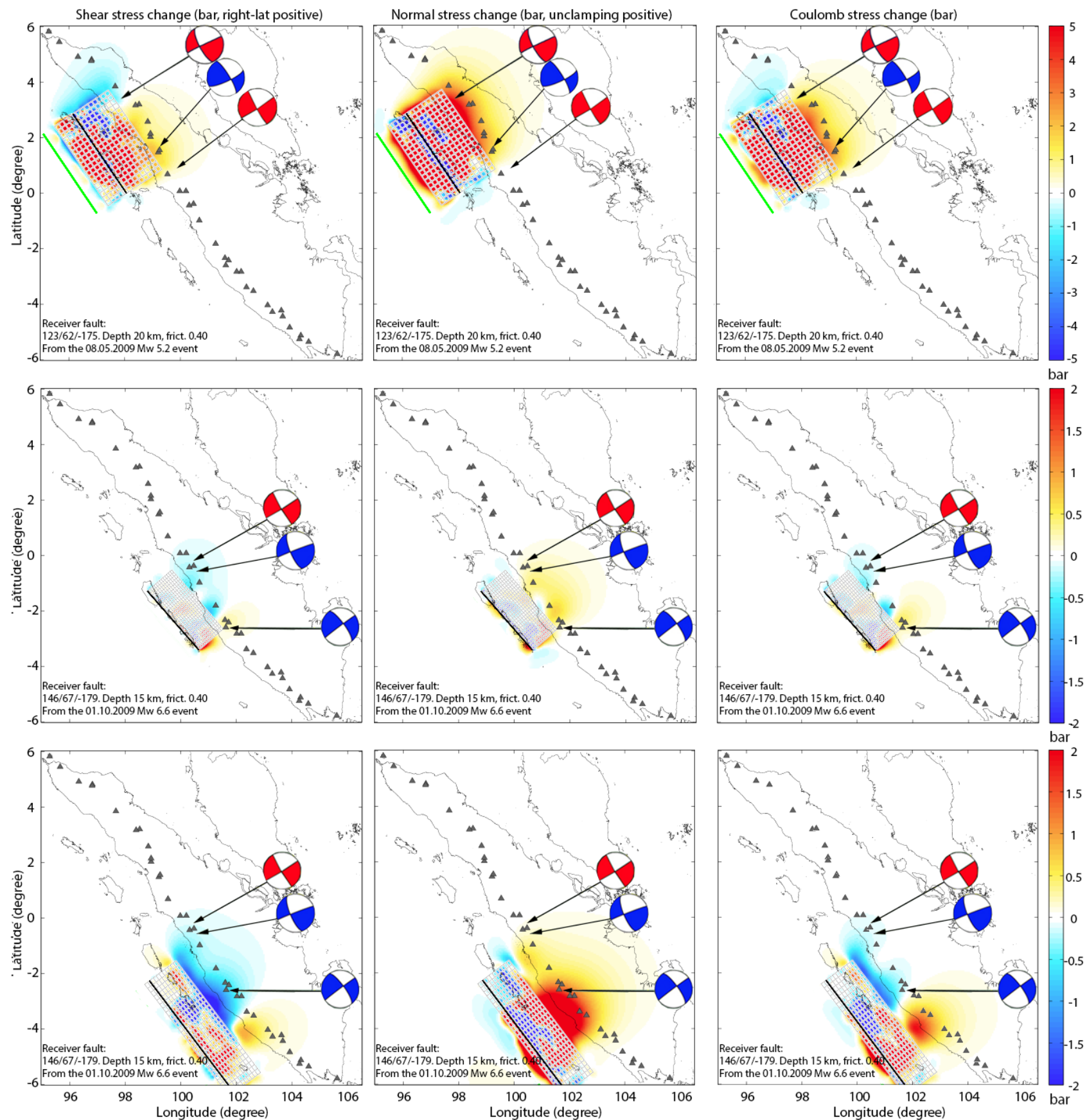

Fig. 4. Coulomb stress analysis for Sumatra. The slip distributions of the events were downloaded from Ji (2013). The first row highlights shear stress, normal stress, and Coulomb stress induced by the 2005 earthquake while the second and third rows indicate effects of the M7.9 and M8.5 2007 earthquakes, respectively. The receiver fault for the northernmost mega-thrust slip (Nias earthquake) is taken from the fault plane solution of the M5.2 event that occurred on 8 May 2009. Depth of the event and strike, dip, and rake angles are shown in each box. For the M7.9 and M8.5 mega-thrust earthquakes we selected the fault plane solution identified by the M6.6 event that occurred on 1 October 2009.

Great Sumatran Fault, while in southern Chile the arc is cut by the Liquiñe-Ofqui transform system. The LiquiñeOfqui terminates around $38^{\circ} \mathrm{S}$ and towards the north the volcanic arc still runs subparallel to the subduction zone.
However, an accurate analysis shows that Chilean and Argentinean volcanoes may also align along apparent NW-SE oriented lineaments, antithetic to the direction of the arc. Interestingly, these lineaments are subparallel to basement 

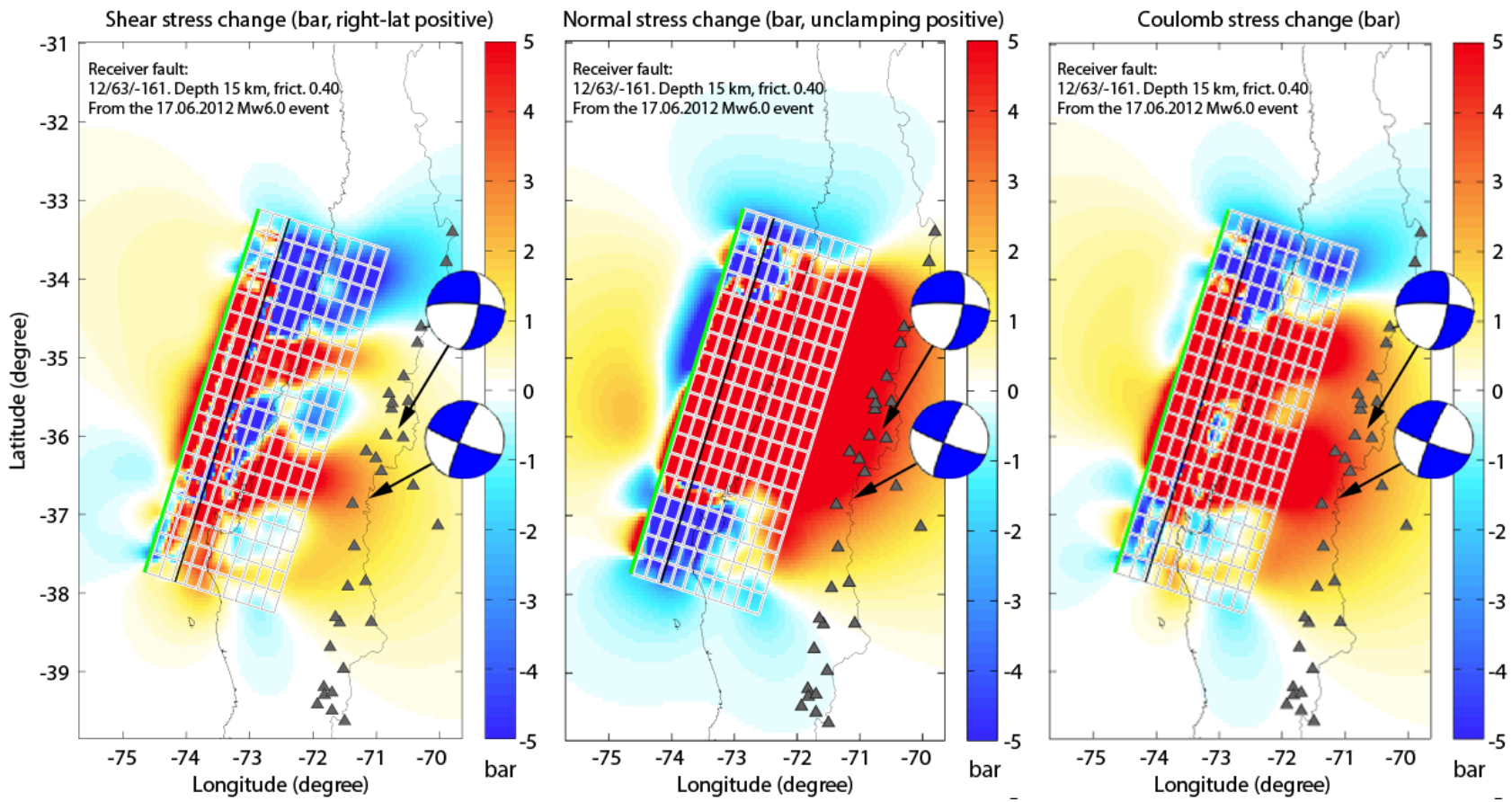

Fig. 5. Shear, normal, and Coulomb stress analysis for Chile. The slip distributions of the Maule earthquake was downloaded from the USGS (2010). The receiver fault, subparallel to the strike of the volcanic arc, is taken from the fault plane solution of the M6.0 event that occurred on 17 June 2012. Depth of the event and strike, dip, and rake angles are shown the boxes.
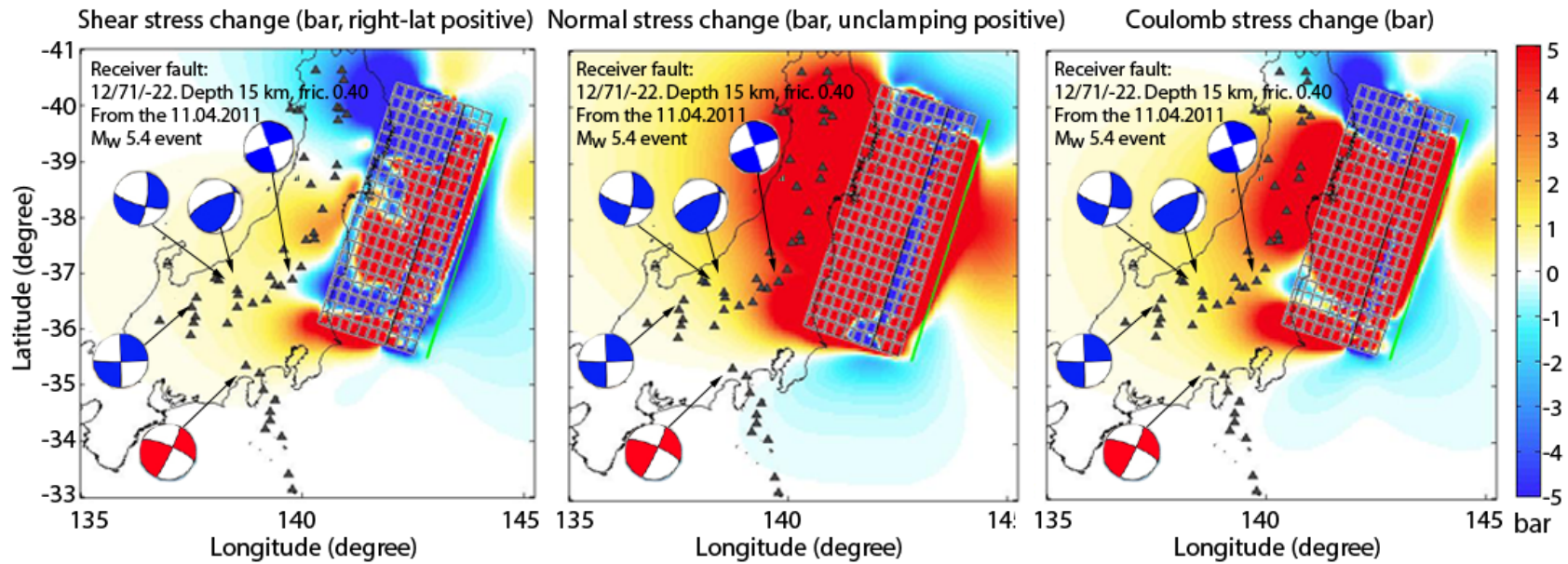

Fig. 6. Coulomb failure calculations of shear, normal, and Coulomb stress induced by the Tohoku-Honshu earthquake on fault plane solutions subparallel to the strike of the volcanic arc. The receiver fault is identified by the focal mechanisms of the M5.4 event in the arc that occurred on 11 April 2011.

NW-SE trending lineaments that have been interpreted as ancient deep structures reactivated as left-lateral strike-slip faults during the development of the volcanic belt (Cembrano and Lara, 2009). Such structures subparallel to the compressional component of the subduction are comparable to the regional-scale lineaments along which Italian volcanic systems align (Rosenbaum et al., 2008). Similar structures have also been identified in northern Fiji, Sulawesi, Indonesia, and at the margins of Calabrian, Caribbean and Scotia arcs (Schellart et al., 2002; Rosenbaum et al., 2008). Cembrano and Lara (2009) highlight that these lineaments can be reactivated by supralithostatic magmatic pressures and our analysis shows that also NW-SE striking faults have been perturbed by mega-thrust earthquakes (Fig. 7).

If the volcanoes in Central Chile are affected by strike-slip motion along NW-SE trending lineaments, then a conjectural 

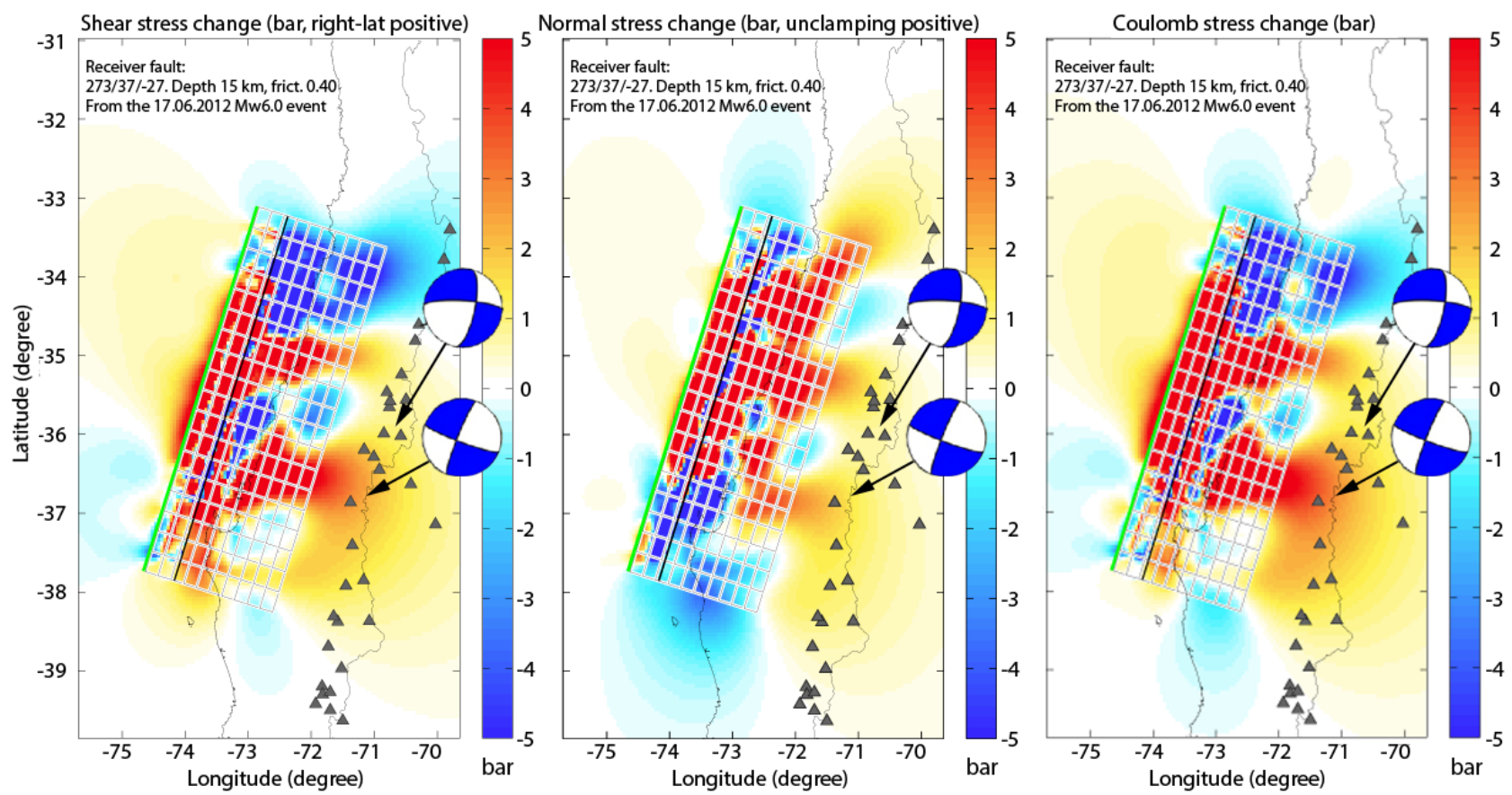

Fig. 7. Shear, normal, and Coulomb stress analysis for Chile using the other fault plane solution of the M6.0 event that occurred on 17 June 2012 (antithetic to the direction of the volcanic arc). The depth of the event and strike, dip, and rake angles are shown the boxes. The Coulomb analysis shows that results similar to the ones in Fig. 5 are obtained when using alternative fault planes. This implies that the Maule earthquake may have perturbed also ancient fault striking at approximately $\mathrm{N} 270^{\circ}$.

mechanism to explain their reactivation would be the "bookshelf mechanism" (Mandl, 1987). According to this, shear stress develops along strike-slip faults during convergence, but as the compressional stress $\sigma_{H}$ is reduced from slip on the subduction zone interface and post-seismic relaxation, deformation is taken up by left-lateral motion along the interfaces of the "books". As stated in Mandl (1987), "[...] when the lateral support is relaxed, the books tilt to one side and shift the plank [...]. The rotation of the books is accompanied by slip between the individual books [...]." Indeed, regions separated by the alignment of Chilean and Argentinean volcanoes resemble tilted books, and faults can be reactivated by slipinduced static stresses.

From a deformation standpoint, we have shown that the reactivation of the strike-slip component in volcanic arcs is a common post-seismic response to mega-thrust subduction zone earthquakes. Strike-slip faulting is initiated by stress transfer from a slip on the subduction interface. Also, the post-seismic increase of crustal hydraulic properties (due to reductions of the normal stress shown in Figs. 4, 5, 6 and 7) promotes the development of this mechanism. The permeability is strongly (e.g. exponentially) dependent on the effective normal stress acting on steeply dipping fractures (e.g. Sibson (1990); Rice (1992); Miller et al. (2004); Sibson (2007)) and vertical diffusion and advection of fast-migrating deep fluids further decrease the effective normal stress at shallower crustal depths (Sibson, 1992; Cox and Ruming,
2004; Lupi et al., 2011). Our Coulomb study provides a first estimate of the variations of normal and shear stresses imposed by the mega-thrust slip. Such (few-bars) variations may affect the equilibrium of magmatic plumbing systems by reducing the confining pressure on magmatic reservoirs (Wicks et al., 2011). This can promote the pressurisation of the magmatic chambers by volatile exsolution and initiate inflation (Druitt et al., 2012). In addition, co-seismic faulting further increases the permeability of the system by creating new fractures (flow paths) inducing fluid pressure cycles that may cause important changes in physical parameters such as seismic velocities, reflectivity, and electrical conductivity within the seismogenic zone (Sibson, 2009). Such coupled and transient permeability fluid-flow behaviours are thought to be relevant in volcanic and hydrothermal systems, as well as in critically stressed geological environments like subduction zones (e.g. Ingebritsen and Sanford, 1999). They may also contribute to the formation of gold deposits (Weatherley and Henley, 2013).

Figure 8 summarises the short-lived switch mechanism that we propose to explain the long-term pulse of increased volcanic activity after mega-thrust earthquakes. Namely, the mega-thrust slip reduces the magnitude of the horizontal stress tensors and $\sigma_{h}$ becomes smaller than $\sigma_{v}$. 

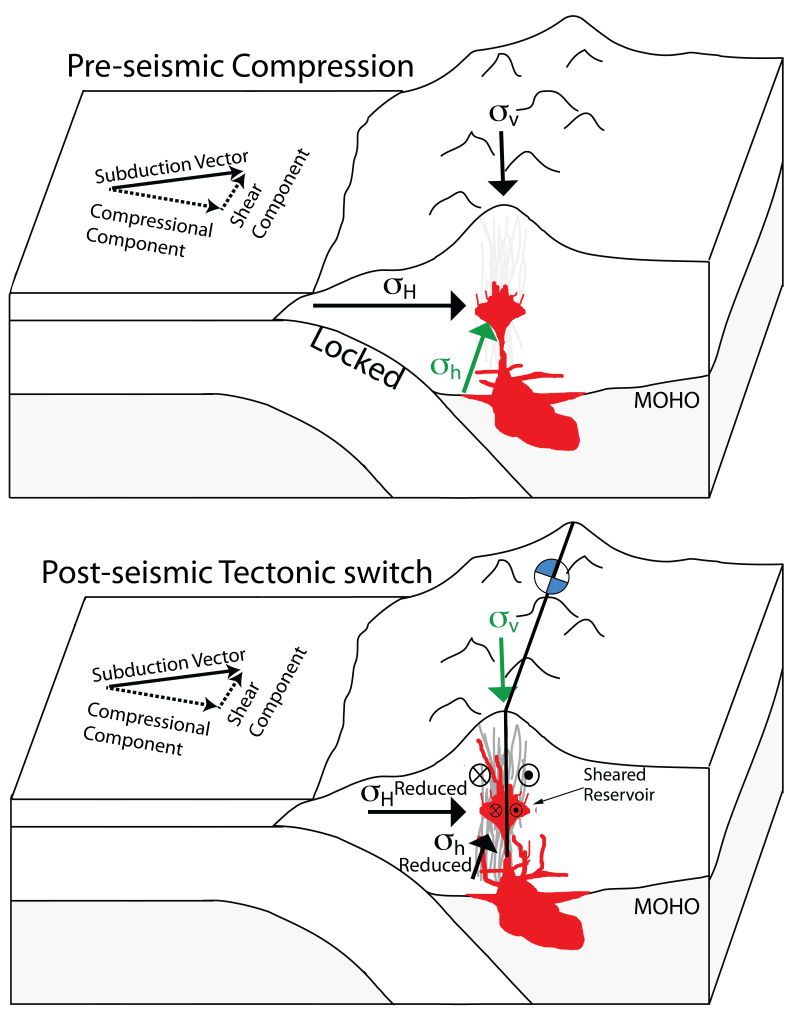

Fig. 8. Simplified representation of the short-lived tectonic switch that takes place in the arc after mega-thrust earthquakes. The green arrow indicates $\sigma_{2}$ and changes from the pre-seismic to the postseismic state due to the reduction of $\sigma_{h}$ as described in Fig. 1. Notice that $\sigma_{H}$ and $\sigma_{h}$ are reduced, while $\sigma_{v}$ remains unchanged. The diagram also highlights the increase of crustal permeability due to lateral motion (darker grey lines).

\section{Conclusions}

We proposed a mechanism to explain the pulsing eruptive rates in volcanic arcs over decades in response to megathrust earthquakes. Our hypothesis is based on the enhancement/establishment of strike-slip regimes in the overriding plate of oblique subduction zones after mega-thrust earthquakes. Beneath the volcanic arc, in regions where preslip $\sigma_{v}=\sigma_{3}$ is close to $\sigma_{h}=\sigma_{2}$, the slip-induced reduction of $\sigma_{H}$ and $\sigma_{h}$ and post-seismic relaxation of compressional stresses cause in the vertical stress $\sigma_{v}$ to adopt the intermediate principal stress. The time delay between megathrust earthquakes and subsequent volcanism reflects the time needed to accommodate the new tectonic loading environment, which depends on the degree of strain-partitioning and shear stress development in the arc. Activation of the (steeply dipping) strike-slip regime then promotes vertical magma migration by providing a shorter pathway to shallow depths and through faulting-induced increases in the permeability structure. Upwelling of deep fluids increases pore pressure along the flow path, and thus the effective nor- mal stress acting on steeply dipping fractures and faults reduces even further, initiating a feedback of fracture, flow, and volatile exsolution.

Coulomb stress transfer analyses for Sumatra, Japan, and Chile all show that strike-slip faults that failed after the megathrust earthquake were brought closer to failure by the main event. Future studies and observations should focus on strikeslip events expected to occur in theses volcanic arcs, with efforts in Central Chile to determine which of the ambiguous focal mechanism solutions is the true fault plane and which is the auxiliary fault plane. We also expect that strike-slip faulting in the arcs of Chile and Sumatra will be followed closely by indicators of a rising magma source, including swarms, inflation, and eruptions. Our hypothesis can be tested in a way that includes (i) structural studies of volcanic arcs to confirm the coexistence of strike-slip and reverse faulting regimes; and (ii) seismic, geodetic, and geochemical networks to capture the expected behaviour described in this paper.

Acknowledgements. The authors thank the Humanitus Sidoarjo fund and the ETH Zurich postdoctoral fellowship program for supporting this study. Discussions with N. Mancktelow and G. L. Cardello are highly appreciated. J.P. Burg and M. Frehner are thanked for commenting the manuscript. We also thank Boris Kaus for reviewing and improving the quality of this manuscript.

Edited by: T. Gerya

\section{References}

AIST, available at: http://riodb02.ibase.aist.go.jp/activefault/index_ e.html, Active fault database of Japan; Last Access date: 13th of June 2013; Year of Publication (of the English Version) 1st of December 2005.

Rapid uplift during the 2007-2012 at Laguna del Maule volcanic field, Andean Southern volcanic zone, 2012.

Bonali, F., Tibaldi, A., Corazzato, C., Tormey, D., and Lara, L.: Quantifying the effect of large earthquakes in promoting eruptions due to stress changes on magma pathway: the Chile case, Tectonophysics, 583, 54-67, doi:10.1016/j.tecto.2012.10.025, 2012.

Braun, J. and Beaumont, C.: Three-dimensional numerical experiments of strain partitioning at oblique plate boundaries: Implications for contrasting tectonic styles in the southern Coast Ranges, California, and central South Island, New Zealand, J. Geophys. Res., 100, 18059-18074, 1995.

Brodsky, E. E. and Prejean, S. G.: New constraints on mechanisms of remotely triggered seismicity at Long Valley Caldera, J. Geophys. Res.-Sol. Ea., 110, B04302, doi:10.1029/2004JB003211, 2005.

Burbidge, D. R. and Braun, J.: Analogue models of obliquely convergent continental plate boundaries, J. Geophys. Res., 103, 15221-15237, 1998. 
Cembrano, J. and Lara, L.: The link between volcanism and tectonics in the southern volcanic zone of the Chilean Andes: a review, Tectonophysics, 471, 96-113, 2009.

Chaussard, E., Amelung, F., and Aoki, Y.: Characterization of open and closed volcanic systems in Indonesia and Mexico using InSAR time series, J. Geophys. Res.-Sol. Ea., 118, 3957-3969, 2013.

Chemenda, A., Lallemand, S., and Bokun, A.: Strain partitioning and interplate friction in oblique subduction zones - constraints provided by experimental modeling, J. Geophys. Res., 105, 5567-5581, 2000.

Cox, S. and Ruming, K.: The St Ives mesothermal gold system, Western Australia - a case of golden aftershocks?, J. Struct. Geol., 26, 1109-1125, 2004.

Darwin, C.: On the connexion of certain volcanic phenomena in South America; and on the formation of mountain chains and volcanoes, as the effect of the same power by which continents are elevated, Trans. Geol. Soc. Lond. 5, (2nd ser.), 601-631, 1840.

Delle Donne, D., Harris, A. J., Ripepe, M., and Wright, R.: Earthquake-induced thermal anomalies at active volcanoes, Geology, 38, 771-774, 2010.

Driessen, J. and Macdonald, C. F.: The troubled island: Minoan Crete before and after the Santorini eruption (Aegaeum 17), Liège and Austin, Aegaeum, 1997.

Druitt, T., Costa, F., Deloule, E., Dungan, M., and Scaillet, B.: Decadal to monthly timescales of magma transfer and reservoir growth at a caldera volcano, Nature, 482, 77-80, 2012.

Duputel, Z., Kanamori, H., Tsai, V. C., Rivera, L., Meng, L., Ampuero, J.-P., and Stock, J. M.: The 2012 Sumatra great earthquake sequence, Earth Planet. Sc. Lett., 351, 247-257, 2012.

Eggert, S. and Walter, T.: Volcanic activity before and after large tectonic earthquakes: observations and statistical significance, Tectonophysics, 471, 14-26, 2009.

Fitch, T.: Plate convergence, transcurrent faults, and internal deformation adjacent to southeast Asia and the western Pacific, J. Geophys. Res., 77, 4432-4460, 1972.

Feigl, K. L., Le Mével, H., Ali, S. T., Córdova, L., Andersen, N. L., DeMets, C. and Singer, B. S.: Rapid uplift in Laguna del Maule volcanic field of the Andean Southern Volcanic zone (Chile) 2007-2012, Geophys. J. Int., doi:10.1093/gji/ggt438, 2013.

Hendrasto, M.: Learn from 2010 Eruptions at Merapi and Sinabung Volcanoes in Indonesia, Annuals of Disas. Prev. Res., 54, 185194, 2011.

Hill, D., Pollitz, F., and Newhall, C.: Earthquake-volcano interactions, Phys. Today, 55, 41-47, 2002.

Ingebritsen, S. and Sanford, W.: Groundwater in Geologic Processes, Cambridge University Press, USA, 1999.

Ji, C.: Large Earthquake Database, available at: http://www.geol. ucsb.edu/faculty/ji/big_earthquakes/home.html, last access: 13th of June 2013.

Johnson, J. and Satake, K.: Asperity distribution of the 1952 great Kamchatka earthquake and its relation to future earthquake potential in Kamchatka, Pure Appl. Geophys., 154, 541-553, 1999.

King, G. C., Stein, R. S., and Lin, J.: Static stress changes and the triggering of earthquakes, B. Seismol. Soc. Am., 84, 935-953, 1994.
Koyama, M.: Mechanical coupling between volcanic unrests and large earthquakes: a review of examples and mechanisms, J. Geogr., 111, 222-232, 2002.

Lipman, P. and Mullineaux, D.: The 1980 eruptions of Mount St. Helens, Washington, US Dept. of the Interior, US Geological Survey, United States Government Printing Office, Washington, D.C., 1981.

Lupi, M., Geiger, S., and Graham, C.: Numerical simulations of seismicity-induced fluid flow in the Tjörnes Fracture Zone, Iceland, J. Geophys. Res., 116, B07101, doi:10.1029/2010JB007732, 2011.

Lupi, M., Saenger, E., Fuchs, F., and Miller, S.: Lusi mud eruption triggered by geometric focusing of seismic waves, Nat. Geosci., 6, 642-646, 2013.

Mandl, G.: Tectonic deformation by rotating parallel faults: the "bookshelf" mechanism, Tectonophysics, 141, 277-316, 1987.

Manga, M. and Brodsky, E.: Seismic triggering of eruptions in the far field: volcanoes and geysers, Annu. Rev. Earth Pl. Sc., 34, 263-291, 2006.

Marzocchi, W., Scandone, R., and Mulargia, F.: The tectonic setting of Mount Vesuvius and the correlation between its eruptions and the earthquakes of the Southern Apennines, J. Volcanol. Geotherm. Res., 58, 27-41, 1993.

Mazzini, A., Nermoen, A., Krotkiewski, M., Podladchikov, Y., Planke, S., and Svensen, H.: Strike-slip faulting as a trigger mechanism for overpressure release through piercement structures, implications for the Lusi mud volcano, Indonesia, Mar. Petrol. Geol., 26, 1751-1765, 2009.

Miller, S., Collettini, C., Chiaraluce, L., Cocco, M., Barchi, M., and Kaus, B.: Aftershocks driven by a high-pressure $\mathrm{CO}_{2}$ source at depth, Nature, 427, 724-727, 2004.

Nakamura, K., Jacob, K. H., and Davies, J. N.: Volcanoes as possible indicators of tectonic stress orientation - Aleutians and Alaska, Pure Appl. Geophys., 115, 87-112, 1977.

Nercessian, A., Hirn, A., and Sapin, M.: A correlation between earthquakes and eruptive phases at Mt Etna: an example and past occurrences, Geophys. J. Int., 105, 131-138, 1991.

Nostro, C., Stein, R., Cocco, M., Belardinelli, M., and Marzocchi, W.: Two-way coupling between Vesuvius eruptions and southern Apennine earthquakes, Italy, by elastic stress transfer, J. Geophys. Res., 103, 24487-24504, 1998.

Pinet, N. and Cobbold, P.: Experimental insights into the partitioning of motion within zones of oblique subduction, Tectonophysics, 206, 371-388, 1992.

Platt, J.: Mechanics of oblique convergence, J. Geophys. Res., 98, 16-239, 1993.

Rice, J.: Fault stress states, pore pressure distributions, and the weakness of the San Andreas fault, International Geophysics Series, 51, 475-475, 1992.

Rosenau, M., Melnick, D., and Echtler, H.: Kinematic constraints on intra-arc shear and strain partitioning in the southern Andes between $38^{\circ} \mathrm{S}$ and $42^{\circ} \mathrm{S}$ latitude, Tectonics, 25, TC4013, doi:10.1029/2005TC001943, 2006.

Rosenbaum, G., Gasparon, M., Lucente, F. P., Peccerillo, A., and Miller, M. S.: Kinematics of slab tear faults during subduction segmentation and implications for Italian magmatism, Tectonics, 27, TC2008, doi:10.1029/2007TC002143, 2008.

Sanchez, J. and McNutt, S.: Intermediate-term declines in seismicity at Mt. Wrangell and Mt. Veniaminof volcanoes, 
Alaska, following the 3 November $2002 \mathrm{Mw} 7.9$ Denali Fault earthquake, B. Seismol. Soc. Am., 94, 6B, S370-S383, doi:10.1785/0120040602004, 2004.

Schellart, W., Lister, G., and Jessell, M.: Analogue modeling of arc and backarc deformation in the New Hebrides arc and North Fiji Basin, Geology, 30, 311-314, 2002.

Sharp, A., Lombardo, G., and Davis, P.: Correlation between eruptions of Mount Etna, Sicily, and regional earthquakes as seen in historical records from AD 1582, Geophys. J. Roy. Astr. S., 65, 507-523, 1981.

Sibson, R.: Conditions for fault-valve behaviour, Geol. Soc. Spec. Publ., 54, 15-28, 1990.

Sibson, R.: Implications of fault-valve behaviour for rupture nucleation and recurrence, Tectonophysics, 211, 283-293, 1992.

Sibson, R.: An episode of fault-valve behaviour during compressional inversion? - The $2004 M_{J} 6.8$ Mid-Niigata prefecture, Japan, earthquake sequence, Earth Planet. Sc. Lett., 257, 188199, 2007.

Sibson, R.: Rupturing in overpressured crust during compressional inversion - the case from NE Honshu, Japan, Tectonophysics, 473, 404-416, 2009.

Sibson, R., Moore, J. M. M., and Rankin, A.: Seismic pumping: a hydrothermal fluid transport mechanism, J. Geol. Soc. London, 131, 653-659, 1975.

Sigmarsson, O., Condomines, M., Morris, J., and Harmon, R.: Uranium and 10Be enrichments by fluids in Andean arc magmas, Nature, 346, 163-165, doi:10.1038/346163a0, 1990.

Sigmarsson, O., Chmeleff, J., Morris, J., and Lopez-Escobar, L.: Origin of 226Ra-230Th disequilibria in arc lavas from southern Chile and implications for magma transfer time, Earth Planet. Sc. Lett., 196, 189-196, 2002.

Sigurdsson, H., Houghton, B., Rymer, H., Stix, J., and McNutt, S.: Encyclopedia of volcanoes, Access Online via Elsevier, 1999.

Stein, R.: The role of stress transfer in earthquake occurrence, Nature, 402, 605-609, 1999.
Tibaldi, A., Pasquarè, F., and Tormey, D.: Volcanism in reverse and strike-slip fault settings, in: New Frontiers in Integrated Solid Earth Sciences, 315-348, doi:10.1007/978-90-481-2737-5, SpringerVerlag, Dordrecht, The Netherlands, 2010.

Tikoff, B. and Greene, D.: Stretching lineations in transpressional shear zones: an example from the Sierra Nevada Batholith, California, J. Struct. Geol., 19, 29-39, 1997.

Toda, S., Stein, R., Sevilgen, V., and Lin, J.: Coulomb 3. 3 Graphicrich deformation and stress-change software for earthquake, tectonic, and volcano research and teaching-user guide, Tech. rep., USGS, 2011.

USGS: USGS online archive of significant earthquakes, Tech. rep., available at: http://earthquake.usgs.gov/earthquakes/ eqinthenews/, USGS, last access: 13th of June 2013, 2010.

Walter, T.: How a tectonic earthquake may wake up volcanoes: stress transfer during the 1996 earthquake-eruption sequence at the Karymsky volcanic group, Kamchatka, Earth Planet. Sc. Lett., 264, 347-359, 2007.

Walter, T. and Amelung, F.: Volcanic eruptions following M 9 megathrust earthquakes: implications for the Sumatra-Andaman volcanoes, Geology, 35, 539-542, doi:10.1130/G23429A.1, 2007.

Weatherley, D. K. and Henley, R. W.: Flash vaporization during earthquakes evidenced by gold deposits, Nat. Geosci., 6, 294298, doi:10.1038/ngeo1759, 2013.

White, R. and Harlow, D.: Destructive upper-crustal earthquakes of Central America since 1900, B. Seismol. Soc. Am., 83, 11151142, 1993.

Wicks, C., de La Llera, J., Lara, L., and Lowenstern, J.: The role of dyking and fault control in the rapid onset of eruption at Chaitén volcano, Chile, Nature, 478, 374-377, 2011.

Williams, S. and Self, S.: The October 1902 plinian eruption of Santa Maria Volcano, Guatemala, J. Volcanol. Geotherm. Res., 16, 33-56, 1983. 